\title{
Copper oxide supported on graphene for phodegradation of Rhodamine B
}

\author{
Nurul Sahida Hassan ${ }^{1}$, Nurul Jamilah Roslani ${ }^{1}$, Aishah Abdul Jalil ${ }^{1,2^{*}}$, Sugeng Triwahyono ${ }^{3,4}$, Nur Fatien Salleh ${ }^{1}$, Nur Farhana Jaafar ${ }^{3}$ \\ ${ }^{1}$ Department of Chemical Engineering, Faculty of Chemical and Energy Engineering, Universiti Teknologi Malaysia, 81310 UTM Johor Bahru, Johor, \\ Malaysia. \\ ${ }^{2}$ Centre of Hydrogen Energy, Institute of Future Energy, Universiti Teknologi Malaysia, 81310 UTM Johor Bahru, Johor, Malaysia. \\ ${ }^{3}$ Department of Chemistry, Faculty of Science, Universiti Teknologi Malaysia, 81310 UTM Johor Bahru, Johor, Malaysia. \\ ${ }^{4}$ Centre for Sustainable Nanomaterials, Ibnu Sina Institute for Scientific and Industrial Research, Universiti Teknologi Malaysia, 81310 UTM Johor Bahru, \\ Johor, Malaysia.
}

*Corresponding Author: aishahaj@utm.my

Article history :

Received 16 November 2015

Accepted 01 December 2015

\section{GRAPHICAL ABSTRACT}

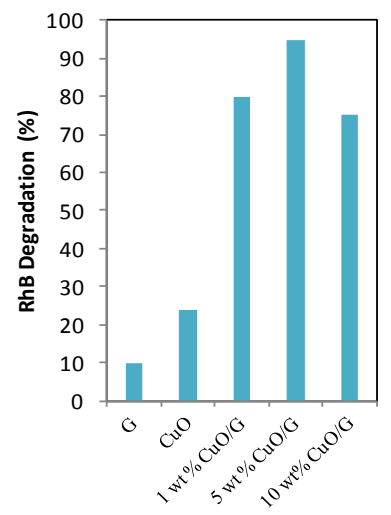

Catalyst

\begin{abstract}
In recent years, dyes are one of the major sources of the water contamination that lead to environmental problems. For instance, Rhodamine $\mathrm{B}(\mathrm{RhB})$ which was extensively used as a colorant in textile industries is toxic and carcinogenic. Among many techniques, photocatalytic degradation become the promising one to remove those dyes from industrial wastewater. Recently, graphene has shown outstanding performance in this application due to its intrinsic electron delocalisation which promotes electron transport between composite photocatalyst and pollutant molecules. While, copper oxide (CuO) is well-known has a lower bandgap energies compared to other semiconductors. Therefore, in this study, copper oxide supported on graphene $(\mathrm{CuO} / \mathrm{G})$ was prepared and its photocatalytic activity was tested on degradation of $\mathrm{RhB}$. The catalysts were characterized by X-Ray Diffraction (XRD) and Fourier Transform Infrared (FTIR) Spectroscopy. The results showed that the interaction between copper and graphene support could enhance the photocatalytic activity. The $5 \mathrm{wt} \% \mathrm{CuO} / \mathrm{G}$ was found to give the highest degradation (95\%) of $10 \mathrm{mg} \mathrm{L}^{-1}$ of $\mathrm{RhB}$ solution at $\mathrm{pH} 7$ using $1 \mathrm{~g} \mathrm{~L}^{-1}$ catalyst after 4 hours under visible light irradiation. The photodegradation followed the pseudo first-order LangmuirHinshelwood kinetic model. This study demonstrated that the $\mathrm{CuO} / \mathrm{G}$ has a potential to be used in photocatalytic degradation of various organic pollutants.
\end{abstract}

Keywords: copper oxide, graphene, photodegradation, rhodamine B

(C) 2015 Penerbit UTM Press. All rights reserved http://dx.doi.org/10.11113/mjfas.v11n4.391

\section{INTRODUCTION}

Dyes widely used in the textile, paper, cosmetics and plastics industries led to severe environmental contamination due to emission of toxic and colored wastewater into water bodies [1]. The discharge of dye was increased about 10,000 tons per year due to many large scale-productions [2]. Rhodamine B $(\mathrm{RhB})$ is a well-known synthetic dye that has been used extensively in textile and printing industries which can contribute to water pollution because of its high solubility in water [3, 4]. In addition, it was toxic and carcinogenic to the humans and other living things when used as a colorant [5].

In a view of the rising awareness toward water quality preservation and improvement, the development of a clean and efficient water purification technology has become the focus for researcher in the last few decades. Various techniques have been developed to remove dyes which include Fenton reagent, ozonation, and electrochemical destruction, adsorption, membrane filtration and ion exchange [6]. However, these techniques suffer from high operational cost and possibility for the generation of secondary pollutant. Among those techniques, heterogeneous photocatalysis has emerged as one of the most powerful methods for water decontamination because of its potential to transform recalcitrant organic contaminants into mineral salts and harmless species such as $\mathrm{CO}_{2}$ and $\mathrm{H}_{2} \mathrm{O}$ [7]. This method involves the utilization of a semiconductor catalyst (such as $\mathrm{TiO}_{2}, \mathrm{ZnO}, \mathrm{Fe}_{2} \mathrm{O}_{3}, \mathrm{CdS}, \mathrm{GaP}$ or $\mathrm{ZnS}$ ) irradiated with light of appropriate wavelength, to generate highly reactive species (i.e., $\bullet \mathrm{OH}, \cdot \mathrm{O}^{2-}, \cdot \mathrm{HO}_{2}$ ) for mineralization of organic impurities. Unfortunately, the insufficient quantum efficiency, narrow excitation wavelength, high recombination rate of the electron-hole pairs, and poor adsorption capacity are the limitation for the practical application of this technique [8]. In order to overcome these problems, a variety of approaches have been attempted including metal particle loading, cocatalysts, dye sensitization, metallic and non-metallic doping. 
Recently, rapid advancements in nanoscience and nanotechnology gained attention toward harnessing the outstanding physicochemical properties of graphene/semiconductors nanocomposites (GSN) for designing new photocatalyst systems. Graphene, as a new material with zero band gap semimetal has the potential to enhance the photocatalytic activity of semiconductors [9]. It can absorb light over a broad range of wavelengths and thus facilitate the visible light catalysis. In addition, the excellent charge trapping ability of graphene nanosheets can be utilized to retard the electron-hole pairs recombination [10]. Moreover, owing to its infinitely large surface-to-volume ratio, graphene has a tendency to adsorb a wide range of synthetic organic compounds as well as inorganic substances [11]. In view of these attractive attributes, photocatalytic performance of copper oxide supported on graphene was investigated. The properties of the catalysts were characterized by XRD and FTIR.

\section{EXPERIMENTS}

\subsection{Catalyst Preparation}

The $\mathrm{CuO} / \mathrm{G}$ was prepared using electrochemical method in accordance with the procedure reported in the literature [12-16]. The process was performed in onecompartment cell equipped with a magnetic stirring bar and two-electrode configuration. A copper plate $(2 \mathrm{~cm} \times 2 \mathrm{~cm})$ anode and a platinum plate $(2 \mathrm{~cm} \times 2 \mathrm{~cm})$ cathode were carefully cleaned using $1.0 \mathrm{M} \mathrm{HCl}$ followed by deionized water before used as electrodes. The electrodes were placed in parallel with a distance of $2.0 \mathrm{~cm}$ and were inserted into the solution of 0.1M TEAP, naphthalene mediator and G (1 $\mathrm{g})$. Then electrolysis was conducted at a constant current of $120 \mathrm{~mA} / \mathrm{cm}^{2}$ and $0^{\circ} \mathrm{C}$ under nitrogen atmosphere. After electrolysis, the mixture was heated at $80^{\circ} \mathrm{C}$ in an oil bath before being dried overnight at $110^{\circ} \mathrm{C}$ and calcined at 300 $\mathrm{K}$ for $3 \mathrm{~h}$. The required copper loading on $\mathrm{G}$ support was calculated based on Faraday's law of electrolysis, as follow:

$n=\left(\frac{I t}{F}\right)\left(\frac{1}{z}\right)$

where $n$ is the number of moles of $\mathrm{Cu}, I$ is constant current of electrolysis (A), $t$ is the total time the constant current was applied (s), $F$ is the Faraday constant $\left(96487 \mathrm{C} \mathrm{mol}^{-1}\right)$, and $z$ is the valency number of ions of the substance (electron transferred per ion). The as-prepared catalyst were obtained and ready to characterize and reaction testing.

\subsection{Characterization of the catalyst}

The study of crystalline structures of the catalysts were carried out using a Bruker Advance D8 X-ray powder diffractormeter $(\mathrm{XRD})$ with $\mathrm{CuK} \alpha$ radiation $(\lambda=1.5418 \AA)$ at $2 \theta$ angle ranging from $20^{\circ}$ to $50^{\circ}$. The chemical functional groups present in the catalysts were identified by FTIR spectroscopy (Perkin Elmer Spectrum GX FTIR Spectrometer). IR absorbance data were obtained over a range of wavenumbers $400-4000 \mathrm{~cm}^{-1}$.

\section{RESULTS AND DISCUSSION}

Fig. 1A shows wide-angle XRD patterns of the catalysts in order to confirm the purity and crystalline structure of the catalysts. The sharp peaks of $\mathrm{CuO}$ at $2 \theta$ of $35.5^{\circ}$ and $38.7^{\circ}$ is attributed to the (111) and (200) plane, respectively (JCPDS Card No. 05 0661). While the G was clearly identified as the carbonaceous material peaks at $2 \theta$ of $26.1^{\circ}$ correspond to (002) plane (JCPDS no. 24-0734) [17]. The XRD pattern of the $\mathrm{CuO} / \mathrm{G}$ catalyst was similar to those $\mathrm{G}$ indicating that the introduction of $\mathrm{Cu}$ did not have much effect on the structure of the catalysts. However, the peak intensity of $G$ seemed to decrease with increasing $\mathrm{CuO}$ loading. This was most probably due to the good distribution of $\mathrm{Cu}$ on the surface of the $\mathrm{G}$ [18].
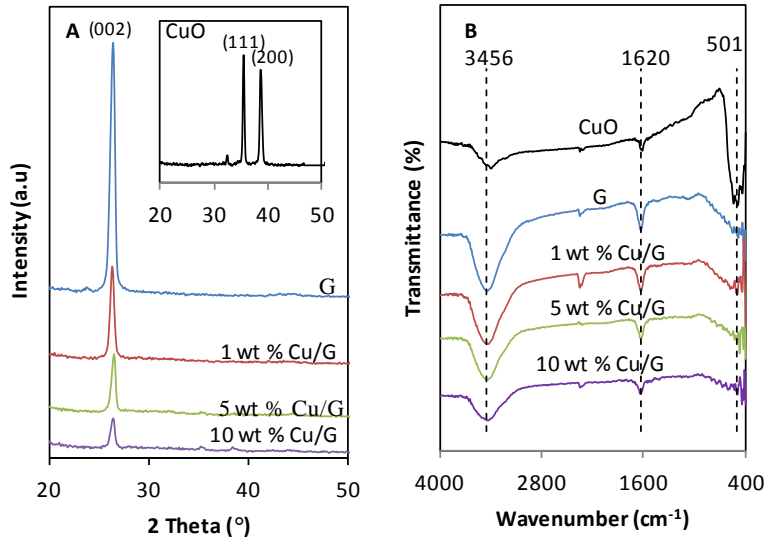

Fig. 1. (A) XRD pattern and, (B) FTIR spectra of the catalysts.

FTIR spectroscopy is analytical technique commonly used to determine the vibrational information about the species of material. Fig. 1B shows the FTIR spectra of $\mathrm{CuO}, \mathrm{G}$ and various loading of $\mathrm{CuO}$ supported on $\mathrm{G}$ catalysts in the region between 4000 and $400 \mathrm{~cm}^{-1}$. For the $\mathrm{CuO}$ sample, a broad band at $501 \mathrm{~cm}^{-1}$ can be assigned as stretching frequency of $\mathrm{Cu}-\mathrm{O}$ bond. Two bands at $3456 \mathrm{~cm}^{-1}$ and $1620 \mathrm{~cm}^{-1}$ were observed for all samples were assigned to adsorb $\mathrm{H}_{2} \mathrm{O}$ molecules. The results illustrated that the intensity of those peaks were decreased with increasing the $\mathrm{CuO}$ loading. This result reveals that higher amount of $\mathrm{CuO}$ loaded onto the $\mathrm{G}$, the hydroxyl group adsorbed on the catalyst's surfaces were fewer due to the $\mathrm{CuO}$ molecules was immersed on the surface of $\mathrm{G}$ during process of electrolysis [19]. Thus, the results demonstrated the combination of catalysts were successful. 


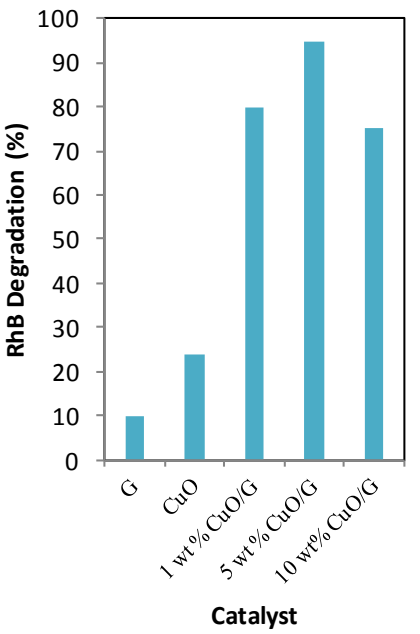

Fig. 2. Catalytic performance of the catalysts $\left([\mathrm{RhB}]=10 \mathrm{mg} \mathrm{L}^{-1}\right.$, $\left.\mathrm{pH}=7, \mathrm{~W}=1 \mathrm{~g} \mathrm{~L}^{-1}, \mathrm{t}=3 \mathrm{~h}, 30^{\circ} \mathrm{C}\right)$.

The photocatalytic performance of $\mathrm{G}, \mathrm{CuO}$, and various loading of $\mathrm{CuO}$ supported on $\mathrm{G}$ was studied with respect to the degradation of $\mathrm{RhB}$ and the results are shown in Fig. 2. Photocatalytic degradation of RhB using $5 \mathrm{wt} \%$ $\mathrm{CuO} / \mathrm{G}$ showed the highest percentage (95\%), followed by $1 \mathrm{wt} \% \mathrm{CuO} / \mathrm{G}(83 \%), 10 \mathrm{wt} \% \mathrm{CuO} / \mathrm{G}(75 \%), \mathrm{CuO}(25 \%)$ and $\mathrm{G}(10 \%)$, signifying the importance of the synergistic effect of $\mathrm{Cu}$ and $\mathrm{G}$ in the system due to the well dispersion of $\mathrm{CuO}$ on the support surface. The degradation of $\mathrm{RhB}$ slightly decreased for $10 \mathrm{wt} \%$ of $\mathrm{CuO}$ loading might be due agglomeration of $\mathrm{CuO}$; thus occurs the pore blockage that reduced surface area and rate of photocatalytic activity as the visible light unable penetrate thoroughly into the catalyst.

The $\mathrm{pH}$ of solution is an important controlling parameter in evaluating an aqueous phase for photocatalytic reaction [20]. In this study, the effect of $\mathrm{pH}$ on the degradation of $\mathrm{RhB}$ using $5 \mathrm{wt} \% \mathrm{CuO} / \mathrm{G}$ was investigated by varying the $\mathrm{pH}$ from 3 to 11 as shown in Fig.3A. The results demonstrated that greatest degradation was obtained at $\mathrm{pH} 7$ with $95 \%$, while degradation at $\mathrm{pH} 3$, 5 , and 11 were $42 \%, 47 \%, 65 \%$, and $50 \%$, respectively. This result could be explained by the amphoteric performance of the catalyst, which is based on its zero point charge $\left(\mathrm{pH}_{\mathrm{ZPC}}\right)$. The $\mathrm{pH}_{\mathrm{ZPC}}$ of the catalyst was found to be at $\mathrm{pH} 5.1$ (inset Fig. 3A); thus, above this $\mathrm{pH}$ value the catalyst surface would be negatively charged and attracted the positively charged $\mathrm{RhB}$, and vice versa [21].

Fig 3B demonstrates the effect of catalyst dosage of $5 \mathrm{wt} \% \mathrm{CuO} / \mathrm{G}$ at $\mathrm{pH}$ 7. It was observed that the degradation was increased by increasing the dosage of the catalyst from 0 to $1 \mathrm{~g} \mathrm{~L}^{-1}$. The highest degradation was achieved when 1 $\mathrm{g} \mathrm{L}^{-1}$ of $5 \mathrm{wt} \% \mathrm{CuO} / \mathrm{G}$, but a further increasing of catalyst dosage resulted a decreasing in degradation. This is because the higher catalyst dosage contributes to the increasing number of active sites that could absorbed more photons and RhB [22]. However, an excess dosage led to the turbidity of suspension in the solution, which reduced the light penetration and impeded the photocatalytic process [23].
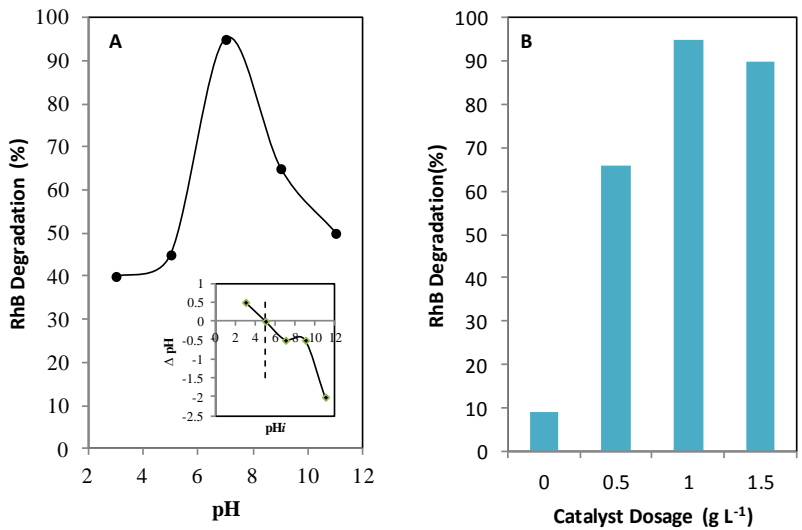

Fig. 3. Effect of (A) $\mathrm{pH}$. Insert figure shows the isoelectric point $\left(\mathrm{pH}_{\mathrm{ZPC}}\right)$ and (B) catalyst dosage of the catalyst $(5 \mathrm{wt} \% \mathrm{CuO} / \mathrm{G}$, $\left.[\mathrm{RhB}]=10 \mathrm{mg} \mathrm{L}^{-1}, \mathrm{t}=3 \mathrm{~h}, 30^{\circ} \mathrm{C}\right)$.

The degradation efficiency of the catalyst also depends on the initial concentration of the substrate. Table 1 demonstrates that the degradation of $\mathrm{RhB}$ was decreased with increasing initial concentration. An increase in initial concentration could inhibited light penetrating to the surface of the catalyst and reduced the formation of the hydroxyl radicals that play important role in degradation of RhB. The kinetic of the catalyst was also being studied using Langmuir-Hinshelwood (L-H) model [24] over 5 wt $\% \mathrm{CuO} / \mathrm{G}$ catalyst and the linear plot of $\ln \left(\mathrm{C}_{\mathrm{o}} / \mathrm{C}_{\mathrm{t}}\right)$ vs. irradiation time are shown in Fig. 4.

Table 1: Percentage degradation at different initial concentrations of $\mathrm{RhB}$ and pseudo-first-order apparent constant values for $\mathrm{RhB}$ degradation using $5 \mathrm{wt} \% \mathrm{CuO} / \mathrm{G}$ $\left(\mathrm{pH}=7, \mathrm{~W}=1.0 \mathrm{~g} \mathrm{~L}^{-1}, \mathrm{t}=3 \mathrm{~h}, 30^{\circ} \mathrm{C}\right)$

\begin{tabular}{cccc}
\hline $\begin{array}{c}\text { Initial } \\
\begin{array}{c}\text { concentration } \\
\text { of } \mathrm{RhB}, \mathrm{C}_{\mathrm{o}} \\
\left(\mathrm{mg} \mathrm{L}^{-1}\right)\end{array}\end{array}$ & $\begin{array}{c}\text { Degradation } \\
(\%)\end{array}$ & $\begin{array}{c}\text { Reaction rate, } \mathrm{k}_{\mathrm{app}} \\
\left(\mathrm{\times} \mathrm{10} \mathrm{mg} \mathrm{L}^{-1} \mathrm{~min}^{-1}\right)\end{array}$ & $\begin{array}{c}\text { Initial rate, } \mathrm{r}_{\mathrm{o}} \\
\left(\mathrm{\times} \mathrm{10} \mathrm{mg} \mathrm{L}^{-2} \mathrm{mg}^{-1}\right)\end{array}$ \\
\hline 10 & 95 & 0.84 & 8.4 \\
30 & 40 & 0.44 & 13.2 \\
50 & 15 & 0.27 & 13.5 \\
70 & 10 & 0.21 & 14.7 \\
\hline
\end{tabular}

All the plots can be roughly fitted to a straight line, indicating the photocatalytic degradation followed pseudofirst-order kinetic model [25]. Table 1 shows that the $\mathrm{k}_{\text {app }}$ decreased with increasing initial concentration, demonstrating the system was favorable at low concentration [26]. The values of $k_{r}$ (reaction rate constant) 


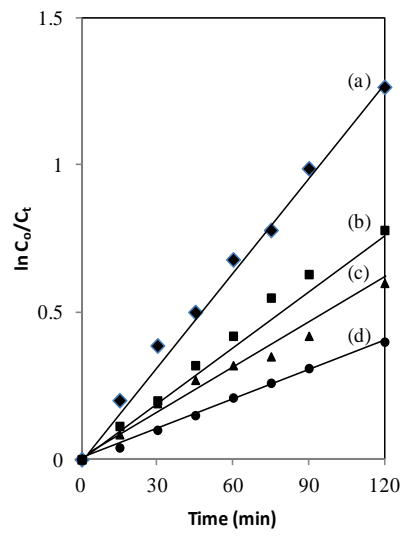

Fig. 4. Photodegradation kinetics of RhB using $5 \mathrm{wt} \% \mathrm{CuO} / \mathrm{G}$ at different initial concentrations (a) 10 , (b) 30 , (c) 50 and (d) $70 \mathrm{mg}$ $\mathrm{L}^{-1}\left(\mathrm{pH}=7, \mathrm{~W}=1.0 \mathrm{~g} \mathrm{~L}^{-1}, \mathrm{t}=3 \mathrm{~h}, 30{ }^{\circ} \mathrm{C}\right)$.

and $K_{L H}$ (adsorption coefficient) were found to be 0.05478 $\mathrm{mg} \mathrm{L}^{-1} \mathrm{~min}^{-1}$ and $0.03776 \mathrm{~L} \mathrm{mg}^{-1}$, respectively. The value of $K_{L H}$ was lower compared with $k_{r}$ signifying that the adsorption of $\mathrm{RhB}$ was the controlling step in the process [27].

\section{CONCLUSION}

$\mathrm{CuO}$ supported on graphene was synthesized using electrochemical method and characterized by XRD and FTIR. The XRD and FTIR results confirmed the presence of $\mathrm{CuO}$ on the surface of graphene. The result showed 5 wt $\% \mathrm{CuO} / \mathrm{G}$ gave the highest degradation $(95 \%)$ of $10 \mathrm{mg}$ $\mathrm{L}^{-1}$ of $\mathrm{RhB}$ solution at $\mathrm{pH} 7$ using $1 \mathrm{~g} \mathrm{~L}^{-1}$ catalyst after 4 hours under visible light irradiation. The kinetic studies shows that the degradation of $\mathrm{RhB}$ followed pseudo first order Langmuir Hinshelwood kinetic model with $\mathrm{kr}$ and $K_{L H}$ value were 0.05478 and 0.03776 respectively. The value of $\mathrm{K}_{\mathrm{LH}}$ was lower compared with $\mathrm{k}_{\mathrm{r}}$ suggesting the reaction would occur on the surface of the catalyst. Therefore, the synthesis of $\mathrm{CuO} / \mathrm{G}$ showed the potential of the catalyst in degradation of $\mathrm{RhB}$.

\section{ACKNOWLEDGEMENTS}

The authors are grateful for the financial support by the Research University Grant from Universiti Teknologi Malaysia (Grant No. 07H06) and the awards of MyPhD Scholarship (Hassan, N. S) from the Ministry of Higher Education.

\section{REFERENCES}

[1] A. A. Jalil, S. Triwahyono, S. H. Adam, N. D. Rahim, M. A. A. Aziz, N. H. H. Hairom, N. A. M. Razali, M. A. Z. Abidin, M. K. A Mohamadiah, J. Hazard. Mater. 181 (2010) 755.

[2] F. Esther, C. Tibor, O. Gyula, Enviro. Inter. 30 (2004) 953.

[3] M. Inoue, F. Okada, A. Sakurai, M. Sakakibara, Ultrason. Sonochem. 13 (2006) 313.

[4] M. R. Chandra, T. S. Rao, S.V.N. Pammi, B. Sreedhar, Mater. Sci. Semicond. Process. 30 (2012) 672.

[5] P. P. Selvam, S. Preethi, P. Basakaralingam, N. Thinakaran, A. Sivasamy, S. Sivanesan, J. Hazard. Mater. 155 (2008)39.

[6] Y. M. Slokar, Dyes Pigm. 37 (1997) 335.

[7] Y. Xu, R. E. Lebrun, Sep. Sci. Tech, 34 (2009) 2501.

[8] K. Zhang, D. Xu, G. Yang, H. Huang, F. Nie, C. Liu, S. Yang, Prog .Mater. Sci, 60 (2014) 208.

[9] A. L. Ivanovskii. 2012. Chem. Rev. 81:571.

[10] Y. Chen, B. Zhang, G. Liu, X. Zhuang, E.T. Kang. Chem. Soc. Rev. 41 (2012) 4688.

[11] H. Wang, X. Yuan, Y. Wu, H. Huang, X. Peng, J. Liang, M. M. Ren. Adv. Colloid Interface Sci. 195 (2013) 19

[12] A. A. Jalil, N. Kurono, M. Tokuda, Synlett 12 (2001) 1944.

[13] A. A. Jalil, N. Kurono, M. Tokuda, Tetrahedron 58 (2002) 7477.

[14] A. A. Jalil, N. Kurono, M. Tokuda, Synthesis 18 (2002) 2681.

[15] N. F. Salleh, A. A. Jalil, S. Triwahyono, J. Efendi, R. R. Mukti, B. Ahmed. Appl. Surf. Sci, 349 (2015) 485.

[16] R. Jusoh, A. A. Jalil, S. Triwahyono, A. Idris, M. Y. Noordin. Sep. Purif. Techno, 149 (2015) 55.

[17] B. Wong,X. Wu, C. Shu, Y. Guo, C. Wang, J. Mater. Chem.20 (2010)10661.

[18] A. A. Jalil, S. Triwahyono, H. D. Setiabudi, N. Sapawe, M. A. H. Satar, A. H. Karim, N. H. N. Kamarudin, R. Jusoh, N. F. Jaafar, N. Salamun, J. Efendi. Appl. Catal A, 468 (2013) 276.

[19] N. W.C. Jusoh, A.A. Jalil, S. Triwahyono, C. R. Mamat. Appl. Catal. A. 492 (2015) 169.

[20] N.W.C. Jusoh, A. A. Jalil, S. Triwahyono, H. D. Setiabudi, N. Sapawe, M.A. H. Satar, A. H. Karim, N. H. N. Kamarudin, R. Jusoh, N. F. Jaafar, N. Salamun, J. Efendi. Appl Catal A. 468 (2013) 276.

[21] A. H. Karim, A.A. Jalil, S. Triwahyono, N.H.N. Kamarudin, A Ripin, J. Colloid Interface Sci. 421 (2014) 93.

[22] V. K. Gupta, A. Rastogi, A. Nayak, J. Colloid Interface Sci. 342 (2010) 135.

[23] I. K. Konstantinou, T.A. Albanis, Appl. Catal. B. 49 (2004) 1.

[24] L. Sun, D. Zhao, Z. Song, C. Shan, Z. Zhang, B. Li, D. Shen, J. Colloid Interface Sci. 363 (2011) 175

[25] A. A. Jalil, M. A. H. Satar, S. Triwahyono, H. D. Setiabudi, N. H. N. Kamarudin, N.F.Jaafar, N. Sapawe, R. Ahamad, J. Electroanal. Chem. 701 (2013) 50.

[26] N. F. Jaafar, A. A. Jalil, S. Triwahyono, M. N. M. Muhd, M.A.H, Satar, H. Asaari, Chem. Eng. J. 191(2012)112.

[27] N. F. Jaafar, A. A. Jalil, S. Triwahyono, N. Shamsuddin, RSC Adv, 5 (2015) 99091 